DOI : $10.14746 /$ ps.2019.1.26

\title{
SIPRI Yearbook 2018. Armaments, Disarmament and International Security and Report from the 3rd Meeting of the Consortium of Academic Departments of Strategic (and Security) Studies
}

Since 1969, the Stockholm International Peace Research Institute (SIPRI) has been publishing a yearbook dedicated to global military expenditure, international arms transfers, arms production, nuclear potential, armed conflicts and multilateral peace operations. The analyses in the yearbook are based on the most recent information on the arms trade, peace and international security. The latest issue (Yearbook 2018) concerns 2017, and focuses on the three issues crucial for the study of peace: armed conflicts and conflict management, military spending and armaments, non-proliferation, arms control and disarmament. Due to the size of the SIPRI Yearbook 2018, this study discusses the most important topics discussed in the Yearbook, in chronological order.

The Introduction to the latest issue argues that the trend which was discussed in the preceding SIPRI Yearbooks (2015, 2016 and 2017), namely the growing number of conflicts breaking out in more and more locations across the globe, and the increasing pace of armament, has been maintained. As was the case before, also in 2017, the long-lasting conflict in Ukraine continued and bordered on confrontation between Russia and the West. This pessimism is rooted in the continuously negative global indicators for peace and security, such as more military spending, flourishing arms trading, increasingly brutal conflicts in the Middle East and parts of Africa, and the continuing advancements in military technology. Additionally, multilateral and bilateral agreements, which are the fundamental components of the armament control system at present, are politically undermined due to mounting strategic competition between the major powers. Firstly, the Treaty on the Prohibition of Nuclear Weapons adopted in 2017 failed to win support from important states, in particular developed states with nuclear potential. Such a decision demonstrates that a potential change is not feasible. Although the Treaty on the Prohibition of Nuclear Weapons was adopted, the nuclear powers continue to clearly oppose it. The essence of the dispute on complete nuclear disarmament boils down to the philosophy of different attitudes to the role of nuclear weapons in international relations. Secondly, the disarmament process initiated during the Cold War is no longer underway, as the currently binding New START expires in 2021 with no prospects for further agreements. Thirdly, the tensions between the major powers (the USA and Russia) have remained stark, particularly due to the annexation of Crimea and continued Russian interference in Ukraine's internal affairs. It can therefore be concluded that the Russian empire has departed from the idea of integration with the West, at least in the short or medium term. NATO has witnessed an internal conflict triggered primarily by the transformation of Turkey during Erdogan's presidency. Another disquieting trend has been maintained in the East, with tensions between India and Pakistan, the growing potential of the People's Republic of China and intensifying rivalry between Iran and Saudi Arabia.

The first section of the SIPRI Yearbook 2018 addresses armed conflicts and conflict management, or rather describes the matters discussed in the Introduction in more detail. Firstly, 
the events in 2017 confirmed the reversal of the post-Cold War disarmament trend identified two years earlier. Additionally, conflicts entered urban areas increasing the civilian death toll by 42 percent compared to 2016. Explosive weapons killed more civilians than military. Forced displacements of civilians reached a record-breaking level of ca. 70 million persons. Food crises were reported in seven countries: Afghanistan, Central African Republic (CAR), Lebanon, Somalia, South Sudan, Syria and Yemen. Secondly, the political situation in the Americas is stabilizing, and in 2017 only Colombia was a stage of active conflict. However, political violence and organized crime failed to be controlled, especially in the largest Latin American cities. Thirdly, in Asia and Oceania alone, five countries were involved in armed conflicts: Afghanistan, India, Myanmar, Pakistan and the Philippines. The sources of those conflicts boil down to the activities of Islamic State, widespread violence and impunity for the security forces of selected countries, and maintaining armaments at a high level. The stabilization of the situation in Nepal and Sri Lanka was an optimistic indicator, at least in 2017. Fourthly, there were two armed conflicts in Eastern Europe: Ukraine and Nagorno-Karabakh (Armenia and Azerbaijan). Unresolved (inactive) conflicts continued on the territories of Cyprus, Georgia (Abkhazia and South Ossetia), Moldova (Transnistria) and Kosovo. West European countries continued their counter-terrorism policy. Fifthly, seven conflicts could be found in the Middle East and North Africa: Egypt, Iraq, Israel and Palestine, Libya, Syria, Turkey and Yemen. The vast majority of them were interconnected through regional powers, as well as external actors. The conflicts were the aftermath of the Arab Spring, a result of regional rivalry between Saudi Arabia and Iran, and of an attempt to revive Islamic State. In Egypt, human rights have not been marginalized to such an extent for decades, and tensions were rising in Sinai. Iraqi authorities faced the challenge of the reconstruction (civilization) of territories once held by Islamic State, especially around Mosul, and of the reconciliation of three very different communities: Shia, Kurdish and Sunni. The war in Syria led to over half of its population being displaced, and 6.5 million were at risk of acute food insecurity, as was the case in Yemen, where Saudi Arabia's actions resulted in 17 million people $(60 \%$ of the population) facing food insecurity. Sixthly, in Sub-Saharan Africa, armed conflicts were active in Mali, Nigeria, Central African Republic, Democratic Republic of Congo, Ethiopia, Somalia and South Sudan. Burundi, Cameroon, Gambia, Kenya, Lesotho, Sudan and Zimbabwe experienced post-war tensions. Events in 2018 confirmed the observation that continued antagonisms were triggered by supranational entities (Islamist groups, criminal networks or armed groups) fueling hatred in people living in extreme poverty, economic instability or corruption, and by the internationalization of the counter-terrorist combat in Africa conducted by France and the United States. Sixthly, in contrast to 2016, 2017 was a hectic year for peacekeeping operations, due to the increased dynamics of stabilization operations. Interestingly, the role of the United Nations was slowly but consistently reducing (a year on year decrease of personnel involved in peacekeeping operations by $7.6 \%$ ) in favor of other entities (a $2.3 \%$ increase in non-UN personnel). The number of peacekeeping operations increased to 63 in 2017, one more than in 2016, but the involvement of regional economic communities in Africa increased significantly. This was mainly due to their reluctance to adopt solutions imposed by the UN under the peace agenda, according to which increased attention is given to political processes taking place in African countries, peace-building and conflict prevention. The extent of the national sovereignty of the host state of peacekeeping operations became increasingly disputable. Additionally, some countries, such as Burundi, the Democratic Republic of the Congo and South Sudan, favored specific assistance, especially military assi- 
stance, and wanted to decide for themselves on the deployment of peacekeeping forces. In 2017, the number of attacks on UN personnel increased suddenly, revealing an inability to respond quickly to such threats. The overall marginalization of United Nations activities is further strengthened by US President Donald Trump, who undermined the sustainability and predictability of financing peacekeeping operations in Africa. The withdrawal of the main international actor, accompanied by the increased dynamics of events, raises the question of whether the UN can do more for less now.

The second section of the SIPRI Yearbook 2018 addresses the issues of military expenditure and armaments. It is stressed at the beginning that, in 2017, it amounted to $\$ 1.7$ trillion, equivalent to 2.2 percent of global GDP or $\$ 230$ per person. Whereas the global increase was 1.1 percent in real terms, it was regionally diverse. Military expenditure in North America fell for the seventh consecutive year ( $0.2 \%$ year on year), while in Eastern Asia it continued to rise for the $23 \mathrm{rd}$ year in succession (4.1\% year on year). In Western Europe, spending increased for the third consecutive year (1.7\% year on year), while in Africa, Central America, the Caribbean and Eastern Europe military spending was lower. Military budgets in the Middle East and South America were higher due to the political situation there. The United States retained their leading position ( $\$ 610$ billion in 2017), China was second ( $\$ 229$ billion in 2017) and Saudi Arabia third ( $\$ 69.4$ billion). Russia's military spending fell by a considerable 20 percent compared to 2016 , to $\$ 66.3$ billion, making it the fourth largest spender in 2017. The latter illustrates the strong interrelation between armament and oil and gas prices. A similar correlation can be seen in Algeria, Angola, Azerbaijan, Ecuador, Iran, Iraq, Kazakhstan, Kuwait, Mexico, Nigeria, Norway, Russia, Saudi Arabia, South Sudan and Venezuela. For these countries, military expenditure between 2014 and 2017 decreased by an average of 16 percent, but the price of oil dropped by over 45 percent. The difference was mostly funded through debt. Importantly, military expenditure transparency leaves much to be desired. There are countries (42 in 2017), including global powers (USA, China, Saudi Arabia and India) that have long failed to duly submit reports on their military spending.

No. of submissions to the United Nations register of conventional arms (SIPRI Yearbook 2018, Summary: 8)

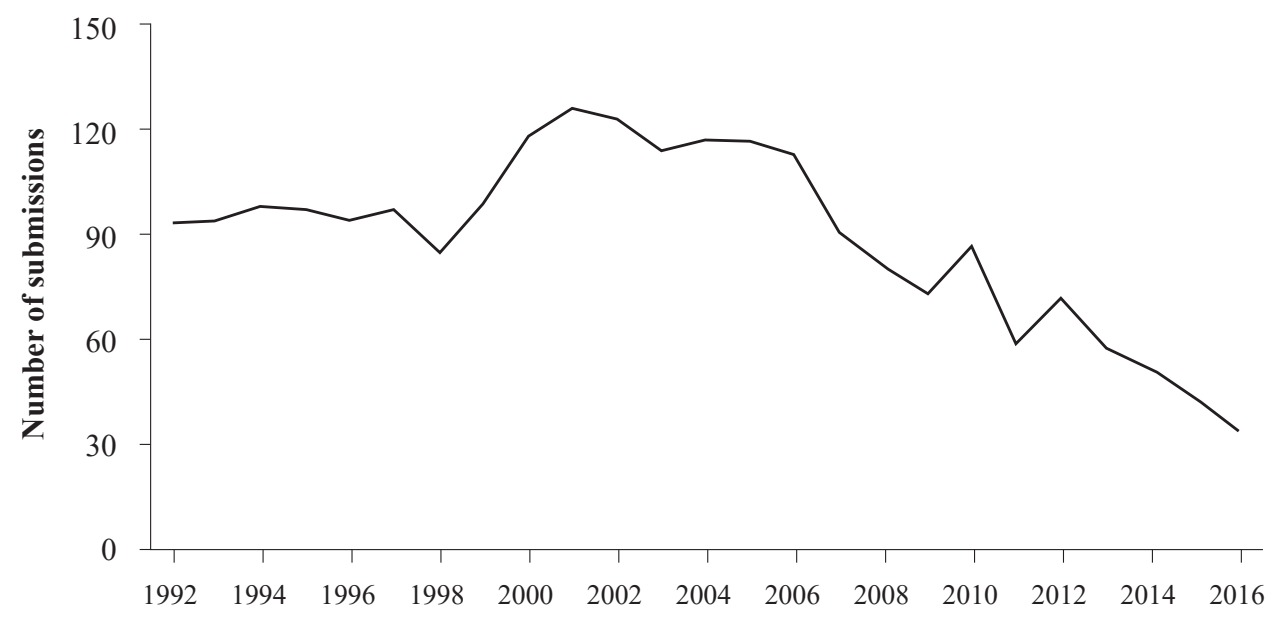


Secondly, the upward trend in international transfers of conventional weapons was maintained in 2017, reaching its highest level since the end of the cold war. The five largest arms suppliers in 2013-17, namely the United States, Russia, France, Germany and China, accounted for 74 percent of the total global volume of exports of weapons. The top five arms importers (India, Saudi Arabia, Egypt, the United Arab Emirates and China) accounted for 35 percent of total arms imports. Importantly, the Middle East increased its purchase of conventional weapons by as much as 103 percent between 2008-12 and 2013-17, contrary to Europe (a decrease by 22 percent), the Americas (a decrease by 29\%), and Africa (by 22 percent).

The trend in transfers of major weapons (SIPRI Yearbook 2018, Summary: 9).

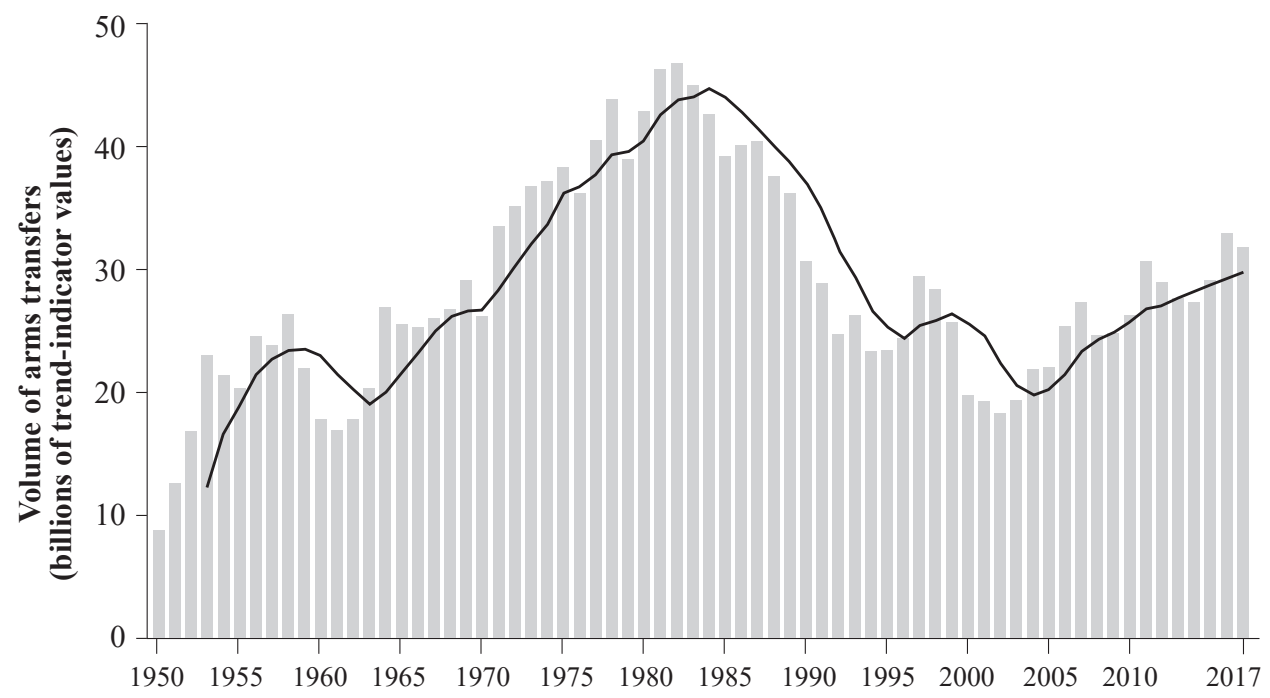

As is the case of military spending, the transparency in conventional arms transfers remains a concern. However, most of the states that have ratified the 2013 Arms Trade Treaty have met their obligation. The total value of the conventional arms trade between states amounted to $\$ 88.4$ billion (in 2016, which is the latest year for which data is available), but the total sales of the top 100 players in the armaments sector (excluding China) totaled almost $\$ 375$ billion (in 2016, which is the latest year for which data is available) marking the first year of increase since 2010. Thirdly, at the beginning of 2018, nine states formed the nuclear club (the United States, Russia, the United Kingdom, France, China, India, Pakistan, Israel and the Democratic People's Republic of Korea) possessing approximately 14,465 nuclear weapons, of which 3,750 were deployed with operational forces, and nearly 2,000 of which are kept in a state of high operational alert. Overall, inventories of nuclear weapons continue to decline, mainly due to the USA and Russia (which collectively account for approximately 92 percent of global nuclear weapons) reducing their strategic nuclear forces in line with the New START. Transparency concerning nuclear weapons leaves a lot to be desired: the USA, the UK and France have disclosed important information; Russia and China refuse to disclose details; India and Pakistan make statements about some of their missile tests; Israel has a policy of not commenting on the topic and North Korea provides no information whatsoever. 
The beginning of the final, third section of the SIPRI Yearbook 2018 (non-proliferation, arms control and disarmament) emphasizes the core of the first Treaty on the Prohibition of Nuclear Weapons (TPNW). The treaty is the first legally binding international agreement to comprehensively prohibit nuclear weapons, with the ultimate goal of their total elimination. This is a response to the frustration of non-nuclear weapon states with the 1968 Treaty on the Non-Proliferation of Nuclear Weapons (NPT) being taken not seriously, even though they acknowledged that it would have no immediate impact on existing nuclear arsenals. Nevertheless, the process of the delegitimization and stigmatization of nuclear weapons has been initiated, which is particularly important in the face of the US's and Russia's reluctance to continue disarmament under the New START, which was strengthened by their conflict over the INF Treaty. Additionally, 2017 saw the intensification of work by the Conference on Disarmament, and the Security Council adopted three additional resolutions imposing new or extended sanctions on North Korea in response to its nuclear weapon and ballistic missile testing activities.

World nuclear forces in 2017 (SIPRI Yearbook 2018, Summary: 11)

\begin{tabular}{||l|c|c|c||}
\hline \hline \multicolumn{1}{|c|}{ Country } & Deployed warheads & Other warheads & Total inventory \\
\hline USA & 1,750 & 4,700 & 6,450 \\
\hline Russia & 1,600 & 5,250 & 6,850 \\
\hline UK & 120 & 95 & 215 \\
\hline France & 280 & 20 & 300 \\
\hline China & - & 280 & 280 \\
\hline India & - & $130-140$ & $130-140$ \\
\hline Pakistan & - & $140-150$ & $140-150$ \\
\hline Israel & - & 80 & 80 \\
\hline North Korea & - & $(10-20)$ & $(10-20)$ \\
\hline Total & $\mathbf{3 , 7 5 0}$ & $\mathbf{1 0 , 7 1 5}$ & $\mathbf{1 4 , 4 6 5}$ \\
\hline
\end{tabular}

Secondly, in 2017, international community endeavored to explain the circumstances of chemical weapon use in Iraq and Syria. The UN Security Council failed to work out a compromise and the talks are most likely to continue next year. Russia, formerly the largest possessor of chemical weapons, completed the destruction of its stockpile in 2017, as required by the 1993 Chemical Weapons Convention (CWC). Towards the end of 2017, the annual Meeting of States Parties (MSP) to the 1972 Biological and Toxin Weapons Convention (BTWC) agreed a further agenda for the period 2018-2020. Thirdly, in 2017, conventional arms control measures were about expanding international humanitarian law. This encounters obstacles resulting, among other things, from the gaps in humanitarian arms control, international law and national regulations pertaining to disarmament. In 2017, negotiations to address the non-proliferation of conventional weapons continued within the framework of the 1981 Convention on Prohibitions or Restrictions on the Use of Certain Conventional Weapons which may be Deemed to be Excessively Injurious or to have Indiscriminate Effects (CCW Convention); the 1997 Convention on the Prohibition of the Use, Stockpiling, Production, and Transfer of Anti-Personnel Mines and on their Destruction (APM Convention); and the 2008 Convention on Cluster Munitions (CCM). After Afghanistan and Lebanon joined, the total number of states parties grew to 125 . In 2017, work began on new regulations for new or emerging technologies, including lethal autonomous weapon systems (LAWS). For the first time, these discussions took place in 
the format of a Group of Governmental Experts (GGE), and addressed the description of systems under consideration and the implications of human-machine interaction. The issue of the use of incendiary weapons and explosive weapons in populated areas, including the use of improvised explosive devices (IEDs) by non-state armed groups, failed to generate new concrete outcomes. The main reason for the lack of consensus was the insufficient number of meetings, further compounded by the fact that come of them were cancelled due to a lack of funding. States parties agreed to discuss both issues further in 2018. As concerns the issue of anti-personnel mines, on the one hand, Sri Lanka and Palestine became the 163rd and 164th states parties to the APM Convention, and Algeria and Mozambique declared themselves free of landmines (nevertheless, 57 states and 4 other areas remained contaminated by mines). On the other one, in 2016 (the most recent data available), global casualties from APMs were at their highest level since 1999, largely as a result of the armed conflicts in Afghanistan, Libya, Ukraine and Yemen. Benin and Madagascar ratified the CCM in 2017, bringing the total number of states parties to 102. Unfortunately, cluster munitions continued to be used in Syria and Yemen. Fourthly, global, regional and multilateral efforts continued in 2017 to strengthen controls on the trade in conventional arms and dual-use items connected with conventional, biological, chemical and nuclear weapons and their delivery systems. The main focus was the development of control standards, promotion principles and implementation measures. The implementation of the 2013 Arms Trade Treaty (ATT) was impeded by tensions between states and non-governmental organizations (NGOs) supporting the treaty. The only solution for now is to report violations of international law to the United Nations, indicate gaps in embargoes, and emphasize the obsolescence of current control measures. The global trend of increasing military spending is working against the ATT, especially in Asia. The greatest concern is the low level of reporting and lack of financial transparency. Thirty-five arms embargoes were in force in 2017: 13 imposed by the UN, 21 by the European Union (EU) and 1 by the League of Arab States. The huge majority of these embargoes covered conventional arms, with the exception of the UN and EU embargoes on Iran and North Korea, and the EU embargo on Russia (dual-use items). 2017 abounded in violations, the scale of which was considerably larger than in the past (investigations by the UN repeatedly revealed large shipments of arms). One arms embargo was imposed in 2017 - on Venezuela. Fifthly, in 2017, trade control lists were updated for each multilateral export control regime - the Australia Group (AG), the Missile Technology Control Regime (MTCR), the Nuclear Suppliers Group (NSG) and the Wassenaar Arrangement on Export Controls for Conventional Arms and Dual-use Goods and Technologies (Wassenaar Arrangement, WA). The goal was to ensure the international community that the control lists continued to cover the often rapid advances in armaments (and account for goods, software and technology). Difficulties with admitting new regime members continued, as exemplified by the response from China and its allies to the admission of India as a WA member (2017) and AG member (beginning of 2018). Sixthly, the issue of intangible transfers of technology (ITT) was not solved in the context of technical data transfer (transfers of knowledge and technical assistance). The main reason for that is the significant compliance costs for companies and research institutes and a lack of knowledge of how to rationally regulate cloud computing and 3D printing.

The final section of the SIPRI Yearbook 2018 traditionally features annexes (synthetic and chronological). The text of the report is available on https://www.sipri.org/ yearbook/2018. 
The issues addressed in SIPRI 2018 were partly discussed at the 3rd Meeting of the Consortium of Academic Departments of Strategic (and Security) Studies.

$$
* * *
$$

\section{Report from the 3rd Meeting of the Consortium of Academic Departments of Strategic (and Security) Studies}

On May 17, 2019, the 3rd Meeting of the Consortium of Academic Departments of Strategic (and Security) Studies took place at the Institute of Political Science and International Relations at the Faculty of International and Political Studies of the Jagiellonian University in Kraków. The speakers, moderators and guests were welcomed by Professor Michał Chorośnicki and Professor Roman Kuźniar.

The speaker in the first panel, entitled "The 70th Anniversary of NATO - a Third Youth or a Swan Song", Professor Arkadiusz Domagała forecasted little or no NATO activity, due not so much to its potential, but to the weak political coherence within the alliance. "After the election of Donald Trump, NATO has become a toolbox of the US." The threat of the political decomposition of the Alliance is further aggravated by Turkey's behavior and the resistance of France and Germany regarding the amount of spending proposed by the American president. The second panelist, Professor Aleksander Głogowski pointed out that in Afghanistan the Alliance had failed to meet the goals set by its decision-makers, which means that it would not continue stabilization activities in the short and medium term. Stabilization effects had not been achieved, despite extensive military action; in particular chaos still reigned and Taliban influence had not been marginalized in Afghanistan. "Outside its target area, NATO will rather implement stabilization tasks after natural disasters, as in Pakistan in 2006." In conclusion, the speaker reminded the audience of the absence of specific provisions under Article 5 and warned about the potential absence of military assistance from the Alliance. Professor Marek Madej also mentioned the difficulties of political cohesion, but he acknowledged the stronger military cohesion of NATO (Wales 2014, Warsaw 2016, Brussels 2018). He observed that NATO strategy was updated every 10 years, but at present, when the time had come for the next update, no talks were even being held. The Alliance should be seen as an entity of regional (European) rather than global security, especially after the bad experience in Afghanistan. The speaker was against treating NATO as a major peacemaker. In his opinion, Russia is the secondary opponent, after the PRC. At the end, he added that the requirement of military spending at the level of $2 \%$ of respective national budgets had emerged during the presidency of Barack Obama, and Donald Trump was only enforcing earlier arrangements. The first panel was concluded with a few comments: Professor Stanisław Koziej spoke of the military significance and political weakness of NATO; Professor Roman Kuźniar indicated that the American presence had a calming effect in the region; Professor Andrzej Mania argued that the lack of a strategy in NATO was not unnatural, because it is the Americans, Chinese or Russians who must have a strategy; Professor Michał Chorośnicki mentioned giving too much attention to tertiary details, such as the Suwalski isthmus; General Anatol Czaban indicated that NATO's potential exceeds that of Russia seventeen times, and that British submarines had been launched; and Dr. Maciej Magiera commented on the 'conservative revolution' in Europe and its consequences for institutional cohesion. 
The second panel, entitled "The EU/CSDP versus the pressure from power politics" began with an introduction by Professor Roman Kuźniar who spoke about Donald Trump's transactional attitude in international politics and concluded that "there is no power without the state." Professor Stanisław Koziej, as the first speaker, presented three scenarios for the role of the EU in the modern world, and considered that of the EU (economic potential) coexisting with NATO (military potential) most likely. However, a problem remains of how to divide tasks in such a tandem. The second speaker, Professor Janusz Węc, argued that transatlantic activity would continue to be divided into NATO military operations and EU crisis management as was the case in the past. However, he stressed the EU's internal need for hard power, although there is a problem with command and transportation systems, etc. The last speaker, Dr. Bartłomiej Nowak, continued the line of thought of his predecessors, adding that over the last five years, mainly since Russia's intervention in Ukraine, the ESDP had changed more than throughout the 70 years of NATO. Due to EU diversity, based on the 'integration complex', the joint defense capability of the EU is anticipated to be achieved within about 15 years. Summarizing the panel, Professor Roman Kuźniar stressed the significant role of Germany in EU defense policy, and more precisely 'German restraint' in spending on armaments.

The third panel, entitled "Dispute over Africa - the policy of powers towards Africa" was opened by General Anatol Czaban, and then the first panelist, Professor Jacek Pawłowski discussed the negative impact that vast uncontrolled areas in Africa have on international relations and their perception. The next speaker, Professor Kamila Pronińska emphasized the significant increase in military (international) involvement in African armed conflicts, which results from various powers (Europe, the USA, China) readying themselves for international rivalry. They even resort to the 'instrumentalization of dissatisfied persons,' which means persuading indigenous populations to perpetrate criminal and terrorist activities. The last speaker, Dr. Ewa Szczepankiewicz-Rudzka, expanded this theme and added that any change in Maghreb (and probably in the rest of Africa) is possible only with the support of the army. However, one cannot take shortcuts and use the army for the forceful democratization of the Maghreb countries ('wild democratization').

Maciej MAGIERA 